\title{
THE MENTAL HEALTH OF FIRST- AND FINAL-YEAR PRECLINICAL MEDICAL STUDENTS
}

\author{
Michelle Stephanie ${ }^{1 *}$, Charles Surjadi ${ }^{1}$ \\ ${ }^{1}$ Fakultas Kedokteran dan IImu Kesehatan, Universitas Katolik Indonesia Atma Jaya Jakarta, Jakarta - INDONESIA
}

Submitted: 10 December 2019; Final Revision from Author: 10 October 2020; Accepted: 15 October 2020

\begin{abstract}
Background: Medical students consistently have higher rates of mental health problems, these include higher levels of stress, anxiety, and burnout, alongside low levels of overall health, and energy. The study aimed to determine the prevalence and the factors influencing the mental health of first-and final-year preclinical students in Unika Atma Jaya.
\end{abstract}

Methods: A cross-sectional study was conducted on all first-year preclinical students (196 respondents) and all final-year preclinical students (115 respondents) using Self Reporting Questionnaire (SRQ). Data were then analyzed using MannWhitney U test, chi square, and Fisher's exact test.

Results: 95 out of 196 (48.5\%) of first-year students and 22 out of 115 (19.1\%) of final-year students have SRQ score of $\geq 6$. Mental health of first-year students were found to be related to their religion and personal life events. Meanwhile factors affecting the mental health of final-year students were their motivation in enrolling to medical school and personal life events.

Conclusion: There is a significant difference of mental health in first-and final-year students (48.5\% and 19.1\%). This may be related to their religion, personal life events, and their motivation in enrolling to medical school.

Keywords: mental health, medical students, self reporting questionnaire

\begin{abstract}
ABSTRAK
Latar Belakang: Mahasiswa kedokteran secara konsisten memiliki prevalensi masalah kesehatan mental yang lebih tinggi. Hal ini termasuk stres, kecemasan, dan burnout yang tinggi, serta nilai kesehatan umum, dan energi yang rendah. Penelitian ini bertujuan untuk mengetahui prevalensi dan faktor-faktor yang memengaruhi kesehatan mental pada mahasiswa preklinik tingkat pertama dan tingkat terakhir di Unika Atma Jaya.

Metode: Penelitian potong lintang dengan membagikan kuesioner tentang latar belakang responden dan Self Reporting Questionnaire (SRQ) kepada seluruh mahasiswa preklinik tingkat pertama (196 responden) dan seluruh mahasiswa preklinik tingkat terakhir (115 responden). Analisis data menggunakan uji Mann-Whitney $U$, chi square, dan Fisher's exact test.

Hasil: 95 dari 196 (48,5\%) mahasiswa tingkat pertama dan 22 dari 115 (19,1\%) mahasiswa tingkat terakhir memiliki nilai SRQ $\geq 6$. Terdapat hubungan antara kesehatan mental mahasiswa tingkat pertama dengan agama dan peristiwa hidup. Sedangkan pada mahasiswa tingkat terakhir, yang berhubungan dengan kesehatan mental adalah keinginan mereka masuk fakultas kedokteran, serta peristiwa hidup.
\end{abstract}

$\overline{\text { *corresponding author, contact: michellestephanie@outlook.com }}$ 
Kesimpulan: Kesehatan mental pada mahasiswa preklinik tingkat pertama dan terakhir (48,5\% dan 19,1\%) berbeda signifikan. Hal ini mungkin berkaitan dengan agama, adanya peristiwa hidup, serta keinginan mereka masuk fakultas kedokteran.

Kata kunci: kesehatan mental, mahasiswa kedokteran, self reporting questionnaire

\section{PRACTICE POINTS}

- Menggali lebih dalam mengenai masalah kesehatan mental mahasiswa kedokteran

- Memberikan informasi kepada pembaca mengenai masalah kesehatan mental mahasiswa kedokteran

\section{PENDAHULUAN}

Saat ini kesehatan mental merupakan masalah global yang signifikan, terutama dengan bertambahnya terus prevalensi tiap tahunnya sejak 2005. ${ }^{1}$ Dari hasil Global Burden of Disease Study (GBD) tahun 2017, prevalensi gangguan mental dan penyalahgunaan zat di dunia mencapai 13,17\%. Walaupun gangguan mental tidak termasuk dalam 30 besar penyakit dalam hal prevalensi maupun insidensi, namun gangguan mental selalu merupakan salah satu penyebab utama masalah kesehatan dan disabilitas di dunia., ${ }^{3,4}$ Di Indonesia, dari hasil Riset Kesehatan Dasar (Riskesdas) 2018, ${ }^{5}$ persentase populasi umum yang mengalami gangguan mental emosional adalah 9,8\%, meningkat dari hasil Riskesdas tahun 2013 yaitu $6 \%{ }^{6}$

Dari hasil GBD 2016, ditemukan bahwa pada dewasa muda, gangguan mental dan penyalahgunaan zat merupakan penyebab disabilitas yang utama. ${ }^{3}$ Selain itu, kematian yang diakibatkan oleh bunuh diri merupakan penyebab kedua terbanyak kematian pada kelompok usia 15-29 tahun. ${ }^{4}$ Dari hasil World Health Organization (WHO) World Mental Health Surveys International College Student Project tahun 2015, didapatkan bahwa 31\% mahasiswa mengalami common mental disorders selama 12 bulan terakhir. ${ }^{?}$ Hal ini tentunya juga dialami oleh mahasiswa yang menjalani pendidikan di fakultas kedokteran (FK) karena mayoritas dari mereka masuk dalam rentang usia tersebut.

Perjalanan untuk menjadi seorang dokter sungguh membutuhkan kerja keras baik secara mental, fisik, maupun emosional, dimulai dari panjangnya waktu yang dilewati sebagai mahasiswa kedokteran, hingga pelatihan sebagai dokter muda. Untuk sebagian besar dari mereka, kondisi seperti ini berdampak buruk bagi diri mereka, dan dapat memicu terjadinya stres, kelelahan, kecemasan, depresi, keinginan bunuh diri, atau bahkan penyalahgunaan zat seperti kanabis, kokain, ataupun obat-obatan psikotropika.

Selama beberapa dekade belakangan ini, para peneliti telah menyadari bahwa stres dalam pendidikan kedokteran merupakan hal yang signifikan serta prevalensi gangguan kesehatan mahasiswa kedokteran yang lebih tinggi dibandingkan rekan sebayanya. ${ }^{8}$ Dari kebanyakan penelitian-penelitian sebelumnya di berbagai negara maju maupun berkembang ${ }^{8-10}$, common mental disorders terjadi pada sekitar 30\% mahasiswa kedokteran. Namun, seperti penelitian di Syria, mahasiswa juga terpapar langsung terhadap efek perang yang sudah terjadi bertahuntahun, sehingga prevalensinya common mental disorders disana pun menjadi jauh lebih tinggi, yaitu 60,6\%. ${ }^{11}$ Perbedaan prevalensi yang ditemukan pada penelitian-penelitian sebelumnya dapat diakibatkan oleh banyak sekali faktor, misalnya perbedaan alat ukur yang digunakan, perbedaan kurikulum FK antar negara, situasi politik yang sedang berlangsung, keadaan sosio-ekonomi, budaya setempat, serta agama yang dianut pada sampel tersebut.

Secara konsisten, mahasiswa kedokteran menunjukkan masalah mental seperti stres, kecemasan, dan burnout yang tinggi, serta nilai kesehatan umum, energi, dan fungsi fisik yang lebih rendah. Selain itu, gangguan kesehatan mental pada mahasiswa kedokteran dapat juga dipandang dari segi 
kesehatan publik dikarenakan masalah kesehatan mental tersebut berlanjut setelah mereka menjadi dokter dan mengakibatkan berkurangnya empati serta menaikkan kejadian kesalahan medis. ${ }^{12,13}$ Oleh karena pentingnya perhatian terhadap kesehatan mental mahasiswa kedokteran, penelitian ini bertujuan utama untuk mengetahui prevalensi masalah kesehatan mental serta faktor-faktor yang berhubungan terhadap kesehatan mental mahasiswa kedokteran preklinik tingkat pertama dan terakhir di Fakultas Kedokteran Unika Atma Jaya.

\section{METODE}

Penelitian ini mengambil pendekatan deskriptif analitik cross-sectional dengan menggunakan kuesioner pada seluruh mahasiswa preklinik tingkat pertama dan seluruh mahasiswa preklinik tingkat terakhir yang sedang mengikuti kepaniteraan umum periode pertama di Fakultas Kedokteran Unika Atma Jaya Jakarta tahun 2019. Alat pengambilan data yang digunakan adalah kuesioner yang berisikan informed consent, latar belakang responden dan Self Reporting Questionnaire dari WHO untuk mengukur kesehatan mental mahasiswa.

Kuesioner latar belakang responden berisi pertanyaan mengenai tingkat perkuliahan yang sedang dijalani responden saat mengisi kuesioner (tingkat pertama atau tingkat terakhir preklinik), jenis kelamin, agama (Katolik, Kristen Protestan, Islam, Buddha, Hindu, dan lainnya), tempat tinggal (tinggal sendiri di kos, bersama teman, atau dengan keluarga), keinginan masuk FK (minat sendiri atau dorongan eksternal), dukungan finansial $(<\mathrm{Rp} 2.000 .000, \mathrm{Rp}$ 2.000.000-Rp 4.000.000, atau >Rp 4.000.000), dukungan emosional (dari non-profesional (misalnya dari teman, keluarga, diri sendiri) atau professional (psikiater atau psikolog)), aktivitas fisik ( $<3 \mathrm{x} / \mathrm{minggu}$ (30-50 menit/sesi) atau $\geq 3 \mathrm{x} /$ minggu (30-50 menit/ sesi), kesehatan fisik (ada tidaknya penyakit fisik kronis), ada atau tidaknya riwayat gangguan mental individu dan keluarga inti, peristiwa hidup/life events (ada atau tidaknya peristiwa yang dirasa mengganggu kehidupan).

Self Reporting Questionnaire merupakan instrumen dari WHO untuk menapis adanya gejala gangguan kesehatan mental yang dibuat terutama untuk digunakan di negara berkembang. Alat ini digunakan untuk penapisan yang lebih umum (nonspecific psychological distress) dengan gejala neurotik, jadi tidak digunakan untuk penapisan spesifik depresi maupun kecemasan.

Untuk pengisian kuesioner Self Reporting Questionnaire, responden juga diminta untuk mengisi masing-masing butir dengan jawaban "ya" atau "tidak" sesuai dengan keadaan responden. Jawaban "ya" bernilai 1, dan jawaban "tidak" bernilai 0 . Keseluruhan dari jawaban dijumlahkan dengan cutoff 6 dari 20 item (berpatokan pada Riskesdas dan situs Kementrian Kesehatan yang sudah divalidasi), sehingga responden dikelompokkan menjadi kelompok dengan nilai SRQ yang $\geq 6$ ataupun $<6$ sebagai gambaran status kesehatan mentalnya. Kemudian dilakukan editing, coding, entry dan cleaning data, serta dianalisis menggunakan uji Mann-Whitney $U$, chi square, dan Fisher's exact test jika terdapat $\mathrm{n}<5$.

Penelitian ini sudah mendapatkan persetujuan etika penelitian dari Komisi Ethical Clearance Unika Atma Jaya (NO: 15/1/KEP-FKUAJ/2019). Pengambilan data menggunakan informed consent secara tertulis. Informasi mengenai responden dirahasiakan dan hanya digunakan untuk kepentingan penelitian.

\section{HASIL DAN PEMBAHASAN}

Penelitian ini dilaksanakan di Fakultas Kedokteran Unika Atma Jaya pada Januari hingga Maret 2019 dengan responden mahasiswa preklinik kedokteran tingkat pertama dan mahasiswa preklinik kedokteran tingkat terakhir yang sedang mengikuti kepaniteraan umum periode pertama pada tahun 2019 dengan menggunakan kuesioner. Setelah dilakukan pengambilan dan pengolahan data, didapatkan sebanyak 196 dari 196 mahasiswa preklinik kedokteran tingkat pertama (100\%) dan 115 dari 115 mahasiswa preklinik kedokteran tingkat terakhir $(100 \%)$ yang mengisi dan mengumpulkan kembali kuesioner.

Dari data yang didapatkan (lihat Tabel 1), terlihat bahwa gambaran demografi kedua angkatan secara garis besar tidak berbeda jauh. Sebagian besar responden tingkat pertama maupun terakhir adalah perempuan $(63,8 \%$ dan $73,9 \%)$, beragama Katolik $(46,4 \%$ dan $53,9 \%)$, tinggal bersama keluarga 
(49,0\% dan 51,3\%), dan masuk fakultas kedokteran dengan keinginan sendiri (94,9\% dan 96,5\%). 52\% mahasiswa tingkat pertama dan 57,4\% mahasiswa tingkat terakhir mendapatkan dukungan finansial sebesar Rp 2.000.000-Rp 4.000.000 tiap bulannya. Untuk dukungan emosional, 96,4\% mahasiswa tingkat awal dan 98,3\% mahasiswa tingkat terakhir mendapatkannya dari non-profesional.

Tabel 1. Karakteristik Demografi Responden

\begin{tabular}{|c|c|c|c|c|}
\hline \multirow{2}{*}{ Karakteristik } & \multicolumn{2}{|c|}{ Tingkat Pertama } & \multicolumn{2}{|c|}{ Tingkat Terakhir } \\
\hline & $\mathbf{n}$ & $\%$ & n & $\%$ \\
\hline \multicolumn{5}{|l|}{ Jenis Kelamin } \\
\hline Perempuan & 125 & 63,8 & 85 & 73,9 \\
\hline Laki-laki & 71 & 36,2 & 30 & 26,1 \\
\hline \multicolumn{5}{|l|}{ Agama } \\
\hline Katolik & 91 & 46,4 & 62 & 53,9 \\
\hline Kristen Protestan & 62 & 31,6 & 37 & 32,2 \\
\hline Islam & 10 & 5,1 & 4 & 3,5 \\
\hline Buddha & 29 & 14,8 & 11 & 9,6 \\
\hline Hindu & 3 & 1,5 & 0 & 0,0 \\
\hline Lainnya & 1 & 0,5 & 1 & 0,9 \\
\hline \multicolumn{5}{|l|}{ Tempat Tinggal } \\
\hline Tinggal sendiri & 92 & 46,9 & 49 & 42,6 \\
\hline Tinggal bersama teman & 8 & 4,1 & 7 & 6,1 \\
\hline Tinggal bersama keluarga & 96 & 49,0 & 59 & 51,3 \\
\hline \multicolumn{5}{|l|}{ Keinginan Masuk FK } \\
\hline Minat sendiri & 186 & 94,9 & 111 & 96,5 \\
\hline Dorongan eksternal & 10 & 5,1 & 4 & 3,5 \\
\hline \multicolumn{5}{|l|}{ Dukungan Finansial } \\
\hline$<\operatorname{Rp} 2.000 .000$ & 53 & 27,0 & 27 & 23,5 \\
\hline Rp 2.000.000-Rp 4.000.000 & 102 & 52,0 & 66 & 57,4 \\
\hline$>\operatorname{Rp} 4.000 .000$ & 41 & 20,9 & 22 & 19,1 \\
\hline \multicolumn{5}{|l|}{ Dukungan Emosional } \\
\hline Non-profesional & 189 & 96,4 & 113 & 98,3 \\
\hline Profesional & 7 & 3,6 & 2 & 1,7 \\
\hline \multicolumn{5}{|l|}{ Aktivitas Fisik } \\
\hline$<3 \mathrm{x} /$ minggu & 147 & 75,0 & 101 & 87,8 \\
\hline$\geq 3 \mathrm{x} /$ minggu & 49 & 25,0 & 14 & 12,2 \\
\hline \multicolumn{5}{|l|}{ Kesehatan Fisik } \\
\hline Tidak ada penyakit fisik kronis & 192 & 98,0 & 108 & 93,9 \\
\hline Ada penyakit fisik kronis & 4 & 2,0 & 7 & 6,1 \\
\hline \multicolumn{5}{|l|}{ Riwayat Gangguan Mental Individu } \\
\hline Tidak ada riwayat & 190 & 96,9 & 110 & 95,7 \\
\hline Ada riwayat & 6 & 3,1 & 5 & 4,3 \\
\hline \multicolumn{5}{|c|}{ Riwayat Gangguan Mental Keluarga Inti } \\
\hline Tidak ada riwayat & 190 & 96,9 & 111 & 96,5 \\
\hline Ada riwayat & 6 & 3,1 & 4 & 3,5 \\
\hline \multicolumn{5}{|l|}{ Peristiwa Hidup (life events) } \\
\hline Tidak ada & 159 & 81,1 & 102 & 88,7 \\
\hline Ada & 37 & 18,9 & 13 & 11,3 \\
\hline
\end{tabular}


Mayoritas responden tingkat pertama maupun terakhir melakukan aktivitas fisik $<3 \mathrm{x} /$ minggu (75,0\% dan $87,7 \%)$, tidak memiliki penyakit fisik kronis (98,0\% dan 93,9\%), tidak memiliki riwayat gangguan mental individu (96,9\% dan 95,7\%), tidak memiliki riwayat gangguan mental keluarga inti (96,9\% dan 96,5\%), dan tidak sedang mengalami peristiwa hidup yang mengganggu $(81,1 \%$ dan $88,7 \%)$.

Pada penelitian ini, digunakan kuesioner SRQ untuk menilai kesehatan mental mahasiswa. Pada Tabel 2, dapat terlihat berapa banyak mahasiswa tingkat pertama maupun terakhir yang memiliki nilai SRQ $<6$ atau $\geq 6$, serta mean nilai total SRQ yang didapatkan dari kedua tingkatan perkuliahan tersebut. Pada penelitian ini, ditemukan bahwa prevalensi gangguan kesehatan mental (nilai SRQ 26) lebih tinggi pada mahasiswa tingkat pertama $(48,5 \%)$ dibandingkan pada mahasiswa tingkat terakhir (19,1\%). Perbedaan kesehatan mental antar kedua tingkat perkuliahan ini juga bermakna signifikan dengan uji Mann Whitney U. Rata-rata nilai SRQ mahasiswa tingkat pertama adalah 5,86 $\pm 4,530$, sedangkan pada mahasiswa tingkat akhir adalah 3,06 $\pm 3,712$.

Tabel 2. Deskripsi Statistik SRQ

\begin{tabular}{ccccc}
\multirow{2}{*}{ Nilai SRQ } & & \multicolumn{2}{c}{ Tingkat Perkuliahan } & \multirow{2}{*}{$\boldsymbol{p}$} \\
\cline { 2 - 4 } & & Pertama & Terakhir & \\
\multirow{2}{*}{$<6$} & $\mathrm{n}$ & 101 & 93 & \\
& $\%$ & 51,5 & 80,9 & \multirow{2}{*}{0,000} \\
& $\mathrm{n}$ & 95 & 22 & \\
\hline \multirow{2}{*}{ Mean \pm SD } & $\%$ & 48,5 & 19,1 & \\
\hline
\end{tabular}

Hal ini serupa dengan yang dipaparkan dalam penelitian Dyrbye et al, ${ }^{14}$ Farrer et al., ${ }^{15}$ dan Aldiabat et al., ${ }^{16}$ yang juga menemukan prevalensi masalah kesehatan mental yang lebih tinggi pada mahasiswa tingkat pertama. Menurut Moir, ${ }^{17}$ faktor stres karena silabus dan perkuliahan lebih dirasakan oleh mahasiswa tingkat pertama karena mereka masih mengalami fase transisional. Mereka baru saja memasuki lingkungan yang asing, serta terdapat banyaknya hal-hal yang berbeda di perguruan tinggi dibandingkan saat masih berada di sekolah, misalnya dalam hal beban pelajaran. Selain itu, hal ini juga dapat terjadi karena mekanisme koping mereka yang masih kurang baik, kurangnya waktu rekreasi, serta kurangnya waktu tidur. ${ }^{16}$

Dapat dilihat pada Tabel 3 dan Tabel 4, bahwa pada kedua angkatan, faktor peristiwa hidup berhubungan dengan kesehatan mental pada kedua angkatan. Sedangkan faktor agama hanya signifikan berkaitan dengan kesehatan mental mahasiswa tingkat pertama. Selain itu, hal menarik lainnya adalah adanya perubahan signifikansi keinginan mahasiswa masuk FK dari tidak signifikan pada tingkat pertama menjadi signifikan pada tingkat terakhir. 
Tabel 3. Karakteristik Mahasiswa Tingkat Awal terhadap Kesehatan Mentalnya

\begin{tabular}{|c|c|c|c|c|c|}
\hline \multirow{3}{*}{ Karakteristik } & \multicolumn{4}{|c|}{ Nilai SRQ } & \multirow{3}{*}{$p$} \\
\hline & \multicolumn{2}{|c|}{$<6$} & \multicolumn{2}{|c|}{$\geq 6$} & \\
\hline & $\mathbf{n}$ & $\%$ & $\mathbf{n}$ & $\%$ & \\
\hline Jenis Kelamin & & & & & 0,902 \\
\hline Perempuan & 64 & 51,2 & 61 & 48,8 & \\
\hline Laki-laki & 37 & 52,1 & 34 & 47,9 & \\
\hline Agama & & & & & 0,036 \\
\hline Katolik & 54 & 59,3 & 37 & 40,7 & \\
\hline Kristen Protestan & 34 & 54,8 & 28 & 45,2 & \\
\hline Islam & 3 & 30,0 & 7 & 70,0 & \\
\hline Buddha & 9 & 31,0 & 20 & 69,0 & \\
\hline Hindu & 1 & 33,3 & 2 & 66,7 & \\
\hline Tempat Tinggal & & & & & 0,329 \\
\hline Tinggal sendiri & 49 & 53,3 & 43 & 46,7 & \\
\hline Tinggal bersama teman & 2 & 25,0 & 6 & 75,0 & \\
\hline Tinggal bersama keluarga & 50 & 52,1 & 46 & 47,9 & \\
\hline Keinginan Masuk FK & & & & & 0,053 \\
\hline Minat sendiri & 99 & 53,2 & 87 & 46,8 & \\
\hline Dorongan eksternal & 2 & 20,0 & 8 & 80,0 & \\
\hline Dukungan Finansial & & & & & 0,445 \\
\hline$<\operatorname{Rp} 2.000 .000$ & 25 & 47,2 & 28 & 52,8 & \\
\hline Rp 2.000.000-Rp 4.000.000 & 57 & 55,9 & 45 & 44,1 & \\
\hline$>\operatorname{Rp} 4.000 .000$ & 19 & 46,3 & 22 & 53,7 & \\
\hline Dukungan Emosional & & & & & 0,059 \\
\hline Non-profesional & 100 & 52,9 & 89 & 47,1 & \\
\hline Profesional & 1 & 14,3 & 6 & 85,7 & \\
\hline Aktivitas Fisik & & & & & 0,364 \\
\hline$<3 \mathrm{x} /$ minggu & 73 & 49,7 & 74 & 50,3 & \\
\hline$\geq 3 \mathrm{x} /$ minggu & 28 & 57,1 & 21 & 42,9 & \\
\hline Kesehatan Fisik & & & & & 0,356 \\
\hline Tidak ada penyakit fisik kronis & 100 & 52,1 & 92 & 47,9 & \\
\hline Ada penyakit fisik kronis & 1 & 25,0 & 3 & 75,0 & \\
\hline Riwayat Gangguan Mental Individu & & & & & 0,110 \\
\hline Tidak ada riwayat & 100 & 52,6 & 90 & 47,4 & \\
\hline Ada riwayat & 1 & 16,7 & 5 & 83,3 & \\
\hline Riwayat Gangguan Mental Keluarga Inti & & & & & 0,433 \\
\hline Tidak ada riwayat & 99 & 52,1 & 91 & 47,9 & \\
\hline Ada riwayat & 2 & 33,3 & 4 & 66,7 & \\
\hline Peristiwa Hidup (life events) & & & & & 0,011 \\
\hline Tidak ada & 89 & 56,0 & 70 & 44,0 & \\
\hline Ada & 12 & 32,4 & 25 & 67,6 & \\
\hline
\end{tabular}

Pada mahasiswa tingkat pertama, seperti dapat dilihat pada Tabel 3, ditemukan bahwa agama berhubungan terhadap prevalensi gangguan mental. Hal ini terlihat dari prevalensi nilai SRQ $\geq 6$ yang lebih banyak pada mereka yang beragama Islam (70\%), Buddha (69\%), maupun Hindu (66,7\%) dibandingkan pada mahasiswa dengan agama mayoritas di fakultas kedokteran Unika Atma Jaya antara lain Katolik 
$(40,7 \%)$ dan Kristen Protestan (45,2\%). Hal ini mungkin serupa dengan yang ditemukan pada literatur dari luar negeri yang mengatakan bahwa mahasiswa yang berbudaya atau beretnisitas minoritas memiliki kesehatan mental yang lebih rendah karena mereka yang minoritas mungkin merasa terasingkan ataupun terdiskriminasi. ${ }^{18}$ Dalam penelitian ini, faktor budaya tidak diikutsertakan namun diganti dengan faktor agama karena mayoritas mahasiswa FK Unika Atma Jaya yang beretnisitas Tionghoa, yang termasuk etnis minoritas di Indonesia sehingga akan sulit untuk ditentukan mana budaya/etnisitas yang tergolong mayoritas maupun minoritas sebagaimana pada penelitian di luar negeri. Dari penelitian masalah kesehatan mental pada mahasiswa oleh WHO dalam rangka World Mental Health Surveys yang dilakukan Auerbach et al. ${ }^{7}$ di delapan negara maju serta penelitian Olayinka et al. ${ }^{19}$ dari penelitiannya di Nigeria, ditemukan bahwa mereka yang beragama Kristiani memiliki kesehatan mental yang lebih baik dibandingkan mahasiswa tidak beragama karena seringnya dilakukan pertemuan dalam komunitas. Hal ini mungkin membantu dalam menurunkan tingkat stres mahasiswa.

Tabel 4. Karakteristik Mahasiswa Tingkat Akhir terhadap Kesehatan Mentalnya

\begin{tabular}{|c|c|c|c|c|c|}
\hline \multirow{3}{*}{ Karakteristik } & \multicolumn{4}{|c|}{ Nilai SRQ } & \multirow{3}{*}{$p$} \\
\hline & \multicolumn{2}{|c|}{$<6$} & \multicolumn{2}{|c|}{$\geq 6$} & \\
\hline & $\mathbf{n}$ & $\%$ & n & $\%$ & \\
\hline Jenis Kelamin & & & & & 0,348 \\
\hline Perempuan & 67 & 78,7 & 18 & 21,2 & \\
\hline Laki-laki & 26 & 86,7 & 4 & 13,3 & \\
\hline Agama & & & & & 0,677 \\
\hline Katolik & 51 & 82,3 & 11 & 17,7 & \\
\hline Kristen Protestan & 28 & 75,7 & 9 & 24,3 & \\
\hline Islam & 3 & 75,0 & 1 & 25,0 & \\
\hline Buddha & 10 & 90,0 & 1 & 9,1 & \\
\hline Hindu & 0 & 0,0 & 0 & 0,0 & \\
\hline Lainnya & 1 & 100 & 0 & 0,0 & \\
\hline Tempat Tinggal & & & & & 0,713 \\
\hline Tinggal sendiri & 41 & 83,7 & 8 & 16,3 & \\
\hline Tinggal bersama teman & 6 & 85,7 & 1 & 14,3 & \\
\hline Tinggal bersama keluarga & 46 & 78,0 & 13 & 22,0 & \\
\hline Keinginan Masuk FK & & & & & 0,022 \\
\hline Minat sendiri & 92 & 82,9 & 19 & 17,1 & \\
\hline Dorongan eksternal & 1 & 25,0 & 3 & 75,0 & \\
\hline Dukungan Finansial & & & & & 0,090 \\
\hline$<\operatorname{Rp} 2.000 .000$ & 18 & 66,7 & 9 & 33,3 & \\
\hline Rp 2.000.000-Rp 4.000.000 & 57 & 86,4 & 9 & 13,6 & \\
\hline$>\operatorname{Rp} 4.000 .000$ & 18 & 81,8 & 4 & 18,2 & \\
\hline Dukungan Emosional & & & & & 0,347 \\
\hline Profesional & 92 & 81,4 & 21 & 18,6 & \\
\hline Non-profesional & 1 & 50,0 & 1 & 50,0 & \\
\hline Aktivitas Fisik & & & & & 0,300 \\
\hline$<3 \mathrm{x} /$ minggu & 80 & 79,2 & 21 & 20,8 & \\
\hline$\geq 3 \mathrm{x} /$ minggu & 13 & 92,9 & 1 & 7,1 & \\
\hline Kesehatan Fisik & & & & & 0,617 \\
\hline Tidak ada penyakit fisik kronis & 88 & 81,5 & 20 & 18,5 & \\
\hline Ada penyakit fisik kronis & 5 & 71,4 & 2 & 28,6 & \\
\hline
\end{tabular}




\begin{tabular}{|c|c|c|c|c|c|}
\hline \multirow{3}{*}{ Karakteristik } & \multicolumn{4}{|c|}{ Nilai SRQ } & \multirow{3}{*}{$p$} \\
\hline & \multicolumn{2}{|c|}{$<6$} & \multicolumn{2}{|c|}{$\geq 6$} & \\
\hline & $\mathrm{n}$ & $\%$ & $\mathrm{n}$ & $\%$ & \\
\hline $\begin{array}{l}\text { Riwayat Gangguan Mental Individu } \\
\text { Tidak ada riwayat } \\
\text { Ada riwayat }\end{array}$ & $\begin{array}{r}90 \\
3\end{array}$ & $\begin{array}{l}81,8 \\
60,0\end{array}$ & $\begin{array}{r}20 \\
2\end{array}$ & $\begin{array}{l}18,2 \\
40,0\end{array}$ & 0,243 \\
\hline $\begin{array}{l}\text { Riwayat Gangguan Mental Keluarga Inti } \\
\text { Tidak ada riwayat } \\
\text { Ada riwayat }\end{array}$ & $\begin{array}{r}91 \\
2\end{array}$ & $\begin{array}{l}82,0 \\
50,0\end{array}$ & $\begin{array}{r}20 \\
2\end{array}$ & $\begin{array}{l}18,0 \\
50,0\end{array}$ & 0,165 \\
\hline $\begin{array}{l}\text { Peristiwa Hidup (life events) } \\
\text { Tidak ada } \\
\text { Ada }\end{array}$ & $\begin{array}{r}87 \\
6\end{array}$ & $\begin{array}{l}85,3 \\
46,2\end{array}$ & $\begin{array}{r}15 \\
7\end{array}$ & $\begin{array}{l}14,7 \\
53,8\end{array}$ & 0,003 \\
\hline
\end{tabular}

Selanjutnya, faktor keinginan masuk fakultas kedokteran hanya berhubungan dengan kesehatan mental mahasiswa pada tingkat terakhir (tabel 4). Dari empat mahasiswa tingkat akhir yang masuk fakultas kedokteran karena adanya dorongan eksternal, tiga diantaranya memiliki nilai SRQ $\geq 6$. Seperti pada penelitian Moir $^{20}$ dan Auerbach et al., ${ }^{7}$ motivasi mahasiswa fakultas kedokteran penting dalam menjaga kesejahteraan saat berada di FK karena beratnya beban perkuliahan. Mereka dengan motivasi intrinsik memiliki kesehatan mental yang lebih baik karena motivasi memengaruhi cara belajar dan hasil dari proses pembelajaran. Sedangkan mahasiswa dengan motivasi intrinsik rendah cenderung memiliki pikiran untuk drop out karena merasa tidak senang dengan perkuliahan. ${ }^{21}$ Selain itu, motivasi berkuliah di FK yang rendah membuat mahasiswa pada tingkat atas mulai memikirkan apakah mereka benar ingin bekerja dalam bidang medis.

Ada atau tidaknya peristiwa hidup yang mengganggu mahasiswa berpengaruh signifikan terhadap kejadiannya gangguan kesehatan mental pada kedua angkatan, misalnya adanya sakit parah pada individu tersebut maupun kerabat dekat. Peristiwa hidup yang mengganggu dalam hal ini berkaitan dengan kematian anggota keluarga, perceraian, maupun perubahan yang negatif dalam hidup. Pada penelitianpenelitian sebelumnya, ${ }^{8,14,22,23}$ juga ditemukan bahwa tingkat stres maupun burnout ditemukan lebih tinggi pada mereka yang sedang mengalami peristiwa hidup yang negatif karena adanya peristiwa hidup yang negatif dalam setahun kebelakang, berdampak negatif pada kualitas hidup mereka. Pada penelitian ini, peristiwa hidup yang dinilai hanyalah peristiwa hidup yang buruk, akan tetapi dari tinjauan pustaka pada penelitian mahasiswa di Amerika Serikat, ${ }^{24}$ yang rata-rata usia mahasiswa kedokterannya lebih tua dibanding di FK Atma Jaya, peristiwa hidup seperti pernikahan tampak memberi proteksi terhadap gangguan mental. Mereka yang sudah menikah, bertunangan, maupun memiliki pasangan, juga ditemukan mempunyai stres yang lebih rendah dibandingkan mereka yang lajang.

Dalam pelaksanaan penelitian ini terdapat beberapa keterbatasan, misalnya penelitian ini tidak menilai kesehatan mental mahasiswa secara longitudinal sejak tahun pertama hingga terakhir, kemungkinan masih banyaknya faktor-faktor lain yang berpengaruh terhadap kesehatan mental mahasiswa seperti kepribadian dan religiositas, serta tidak dilakukannya intervensi untuk melihat intervensi apa yang dapat diterapkan untuk mengurangi prevalensi masalah kesehatan mental pada mahasiswa fakultas kedokteran.

\section{KESIMPULAN}

Dari hasil penelitian, dapat dilihat bahwa terdapat perbedaan prevalensi gangguan kesehatan mental mahasiswa preklinik tahun pertama dan terakhir di Fakultas Kedokteran Unika Atma Jaya, yaitu 48,5\% mahasiswa tingkat pertama dan 19,1\% mahasiswa tingkat terakhir yang memiliki nilai $S R Q \geq 6$. Rata- 
rata nilai SRQ untuk masing-masing angkatan adalah $5,86 \pm 4,530$, sedangkan pada mahasiswa tingkat akhir adalah 3,06 $\pm 3,712$. Hal ini mungkin terjadi karena pada mahasiswa tingkat pertama belum terjadi adaptasi pada fase transisional ke perguruan tinggi.

Kesehatan mental mahasiswa pada kedua tingkat ditemukan tidak berhubungan dengan jenis kelamin maupun tempat tinggal. Namun agama pada mahasiswa tingkat pertama dan keinginan masuk FK pada mahasiswa tingkat terakhir berhubungan terhadap kesehatan mental. Sedangkan adanya peristiwa hidup yang mengganggu berhubungan terhadap kesehatan mental pada kedua tingkat perkuliahan.

Aktivitas fisik, kesehatan fisik, riwayat gangguan mental individu maupun keluarga inti, dukungan finansial, dan sumber dukungan psikologis tidak ditemukan berhubungan dengan kesehatan mental pada kedua angkatan. Mungkin saja tidak ditemukan signifikansi hubungan faktor-faktor ini dengan kesehatan mental karena kurang beragamnya demografi mahasiswa di FK Atma Jaya.

\section{SARAN}

Dikarenakan terbatasnya waktu pelaksanaan, penelitian ini dilakukan dengan metode crosssectional. Akan tetapi, untuk dapat mencari hubungan antara faktor dengan kesehatan mental yang lebih baik, dapat dilakukan penelitian secara longitudinal untuk menilai tingkat kesehatan mental mahasiswa dari tingkat pertama hingga akhir selama pendidikan di fakultas kedokteran. Selanjutnya, dapat juga dilakukan penelitian antar universitas di Indonesia agar hasilnya dapat lebih digeneralisasi dan representatif terhadap mahasiswa-mahasiswa kedokteran di Indonesia, sekaligus juga untuk membandingkan kesehatan mental mahasiswa kedokteran Indonesia dengan mahasiswa kedokteran luar negeri.

Selain itu, selama dilakukan penelitian ini, ditemukan juga faktor-faktor lainnya yang mungkin berpengaruh terhadap kesehatan mental mahasiswa fakultas kedokteran misalnya kepribadian dan religiusitas mahasiswa sehingga masih ada ruang untuk memperdalam pengaruh faktor-faktor yang sudah diikutsertakan, misalnya faktor agama.

Untuk institusi pendidikan kedokteran, dapat dilakukan berbagai macam intervensi kepada mahasiswa dan dilihat intervensi mana yang paling baik untuk mengurangi prevalensi masalah kesehatan mental pada mahasiswa fakultas kedokteran.

\section{DEKLARASI KEPENTINGAN}

Para penulis mendeklarasikan bahwa tidak terdapat konflik kepentingan apapun terkait studi pada naskah ini.

\section{KONTRIBUSI PENULIS}

Michelle Stephanie - mengumpul, mengolah, dan menganalisis data, serta penulis utama

Charles Surjadi - memberikan umpan balik dan masukan

\section{DAFTAR PUSTAKA}

1. Metrics GH. Global, regional, and national disability-adjusted life-years (DALYs) for 333 diseases and injuries and healthy life expectancy (HALE) for 195 countries and territories, 1990-2016: a systematic analysis for the Global Burden of Disease Study 2016. 2017;390:19902016.

2. Global Burden of Disease Study 2017 Results [Internet]. Seattle; 2017. Available from: http:// ghdx.healthdata.org/gbd-results-tool

3. Metrics GH. Global, regional, and national incidence, prevalence, and years lived with disability for 328 diseases and injuries for 195 countries, 1990-2016: a systematic analysis for the Global Burden of Disease Study 2016. 2017;390:1990-2016.

4. World Health Organization. Depression and Other Common Mental Disorders: Global Health Etimates. Geneva; 2017.

5. Kementrian Kesehatan Republik Indonesia. Hasil Utama Laporan Riskesdas 2018. 2018;

6. Kementrian Kesehatan Republik Indonesia. Riset Kesehatan Dasar. Jakarta; 2013. 
7. Auerbach RP, Bruffaerts R, Mortier P, Alonso J. The WHO World Mental Health Surveys International College Student ProjectPrevalence and Distribution of Mental Disorders. J Abnorm Psychol. 2018;

8. Brazeau CMLR, Shanafelt T, Durning SJ, Massie FS, Eacker A, Moutier C, et al. Distress Among Matriculating Medical Students Relative to the General Population. Acad Med. 2014;89(11).

9. Ohtsu T, Kaneita Y, Osaki Y, Kokaze A, Ochiai $\mathrm{H}$, Shirasawa T, et al. Mental health status among Japanese medical students: A crosssectional survey of 20 universities. Acta Med Okayama. 2014;68(6):331-7.

10. Hersi L, Tesfay K, Gesesew H, Krahl W, Ereg D, Tesfaye M. Mental distress and associated factors among undergraduate students at the University of Hargeisa, Somaliland: A cross-sectional study. Int J Ment Health Syst. 2017;11(1):1-8.

11. Al Saadi T, Zaher Addeen S, Turk T, Abbas F, Alkhatib M. Psychological distress among medical students in conflicts: A cross-sectional study from Syria. BMC Med Educ. 2017;17(1):18.

12. Tawfik DS, Profit J, Morgenthaler TI, Satele D V, Sinsky CA, Dyrbye LN, et al. Physician Burnout, Well-being, and Work Unit Safety Grades in Relationship to Reported Medical Errors. Mayo Clin Proc. 2018 Aug 23;

13. Brazeau CMLR, Schroeder R, Rovi S, Boyd L. Relationships Between Medical Student Burnout, Empathy, and Professionalism Climate. Acad Med. 2010;85(10).

14. Dyrbye LN, Thomas MR, Shanafelt TD. Medical student distress: Causes, consequences, and proposed solutions. Mayo Clin Proc. 2005;80(12):1613-22.

15. Farrer LM, Gulliver A, Bennett K, Fassnacht DB, Griffiths KM. Demographic and psychosocial predictors of major depression and generalised anxiety disorder in Australian university students. BMC Psychiatry. 2016;16(1):1-9.
16. Aldiabat KM, Matani NA, Le Navenec C-L. Mental Health among Undergraduate University Students: A Background Paper for Administrators, Educators and Healthcare Providers. Univers J Public Heal. 2014;2(8):209_ 14.

17. Qamar K, Rizwan M, Kiani B, Ayyub A, Khan AA, Osama M. Journal of Educational Evaluation for Health Professions Higher stress scores for female medical students measured by the Kessler Psychological Distress Scale (K10) in Pakistan. J Educ Eval Heal Prof. 2014;11:10-1.

18. Orom H, Semalulu T, Iii WU. The Social and Learning Environments Experienced by Underrepresented Minority Medical Students : A Narrative Review. 2013;88(11):1765-77.

19. Omigbodun OO, Odukogbe A-TA, Omigbodun AO, Yusuf OB, Bella TT, Olayemi O. Stressors and psychological symptoms in students of medicine and allied health professions in Nigeria. 2006;415-21.

20. Moir F. Empowering Medical Students to Improve Their Mental Health. The University of Auckland; 2013.

21. Pacheco JP, Giacomin HT, Tam WW, Ribeiro TB, Arab C, Bezerra IM, et al. Mental health problems among medical students in Brazil: a systematic review and meta-analysis. Rev Bras Psiquiatr. 2017;(0):369-78.

22. Ngasa SN, Sama C, Dzekem BS, Nforchu $\mathrm{KN}$, Tindong M, Aroke D, et al. Prevalence and factors associated with depression among medical students in Cameroon : a cross-sectional study. 2017;1-8.

23. Dunn LB, Iglewicz A, Moutier C. Promoting Resilience and Preventing Burnout. 2008;(February).

24. Slavin SJ, Schindler DL, Chibnall JT. Medical student mental health 3.0: Improving student wellness through curricular changes. Acad Med. 2014;89(4):573-7. 